\title{
THE SPRINGBOKS IN EAST AFRICA: THE ROLE OF 1 SA SURVEY COMPANY (SAEC) IN THE EAST AFRICAN CAMPAIGN OF WORLD WAR II, 1940-1941
}

\section{Elri Liebenberg ${ }^{1}$ \\ Department of Geography, University of South Africa}

\begin{abstract}
As a member of the British Commonwealth, South Africa was part of Britain's war effort from September 1939 onward. When Italy entered the War on the side of Germany on 10 June 1940, the territories governed by Italy in East Africa comprised Abyssinia together with Eritrea, now part of Ethiopia, and Italian Somaliland, now part of the Somali Democratic Republic. Although pre-war plans did not anticipate that the South African (SA) Army would fight outside southern Africa, Italy's involvement in northeast Africa made it inevitable that SA troops would be deployed to the new war front.
\end{abstract}

The SA forces (nicknamed 'Springboks' in the media) played a major role in the demise of Mussolini's East African Empire. The war was fought under extreme physical conditions, and it was especially the SAEC (South African Engineering Corps) who rendered invaluable service. By 1940 East Africa was still largely unmapped, and one of the SAEC units, 1 SA Survey Company (initially named the 1st Field Survey Company), supported by 60 Photographic Squadron of the SA Air Force (SAAF), mapped large parts of the war zone and provided essential military intelligence.

Although the role the SAEC as a whole played in the East African Campaign has received attention in publications on South Africa's involvement in World War II, little attention has been paid to the essential cartographical services rendered by 1 SA Survey Company. This article deals with the formation and subsequent successful deployment of 1 SA Survey Company in Kenya, and the

Scientia Militaria, South African Journal of Military Studies, Vol 44, No. 2, 2016, pp. 87-112. doi : $10.5787 / 44-2-1177$ former Abyssinia and Somaliland, and the maps it produced for strategic and combat purposes. Attention is given to the operational structure of the Company, the mapping policy 
decisions the Company had to adhere to, the way the company sections operated in the field, the prevailing conditions under which the men worked, and the types of map that were produced.

Keywords: war, map, East Africa, survey, aerial photograph

\section{Introduction}

Although the Union of South Africa had participated in World War I as a dominion of the British Empire, the country was ill prepared for war. By September 1939, the SA armed forces were constituted by a permanent force of only 349 officers and warrant officers, 5033 non-commissioned officers and privates, and an active citizen force comprising 918 officers and warrants and 12572 non-commissioned officers and privates. ${ }^{2}$ The members of the citizen force were volunteers who were required to undergo between one and a half and four hours of non-continuous military training each week, and fifteen days of continuous training every year. ${ }^{3}$ The country also lagged far behind the rest of the world in the fields of military equipment and the production of war materials.

In spite of the deficiencies, the SA government was adamant that the country would fully cooperate with the British Commonwealth against the Axis powers. Immediate measures to expand and mechanise the SA Army and improve the capacity of the SAAF were put in place, and by December 1939, the Mobile Field Force of the Union Defence Force (UDF) had been formed and was being trained and mobilised. ${ }^{4}$ It was clear that, should Italy enter the war, Italian forces operating from Eritrea and Abyssinia would pose a real threat to Allied shipping in the Red Sea and that Germany would support an Italian invasion of Kenya. As a precautionary measure, the UDF sent several reconnaissance parties to Nairobi to report on local conditions. One of the important issues that was investigated was the level of surveying and topographical mapping in northeast Africa.

The probable area in East Africa over which operations were expected to take place, was vast. The Italian area of interest formed a solid block of territory with an area of over $1600000 \mathrm{~km}^{2}$ extending from the border between Kenya and Italian East Africa in the south to the northern boundary of Eritrea, and from the AngloEgyptian Sudan in the west, to the Indian Ocean, British Somaliland, the Gulf of Aden, and the Red Sea in the east (see Figure 1). Very little of this area had been properly surveyed, and there were large tracts for which little cartographic information was available. The most up-to-date published maps of Abyssinia and Italian Somaliland was a 1:400 000 Italian map series, which was publicly available in places such as Mogadishu, but of which only a few sheets had been 
obtained prior to the war. ${ }^{5}$ According to Orpen, the captured Italian maps were also inaccurate and therefore of little use. ${ }^{6}$

By 1939, the only available War Office maps of East Africa were -

- GSGS 2871, the 1:2000 000 standard African map series covering the whole of East Africa;

- GSGS 2465, a 1:1 000000 series of Tanganyika, southern and northwestern Kenya, and Uganda, but without any coverage of Abyssinia or Italian Somaliland; and

- GSGS 1764, a 1: 250000 maps series comprising seventeen sheets covering British Somaliland. ${ }^{7}$

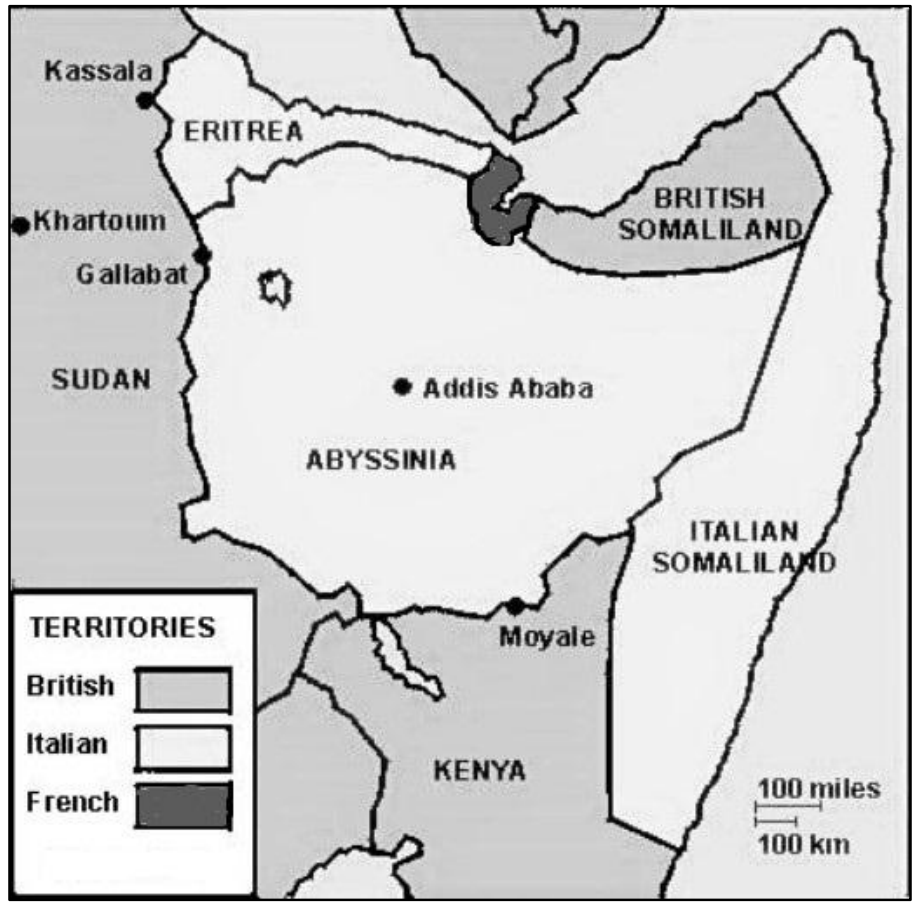

Figure 1. The war zone in northeast Africa in 1939.

With the existing maps being inadequate for a military campaign, the immediate mapping of East Africa became a matter of the utmost urgency. With the resources of the local East African Survey Company in Nairobi severely 
limited, it became clear that South Africa would have to play a leading role in providing the necessary topographical information and maps for military purposes.

\section{Background}

When the Union of South Africa was established in 1910, the country had no central mapping organisation and was virtually unmapped except for a few compilation map series produced by the British forces during the Anglo-Boer War of 1899 to $1902 .^{8}$ After the war, Britain realised that if it wanted to retain its political supremacy in southern Africa it would have to make provision for the systematic mapping of the region. ${ }^{9}$ In 1905, the Colonial Survey Section was sent to South Africa to undertake the topographical mapping of the Orange River Colony at a scale of 1:125 000 (GSGS 2230). ${ }^{10}$ Two other map series which were also undertaken by the War Office after the war were GSGS 1764 which was based on a reconnaissance survey of the north-western Cape Colony and Basutoland from 1903 to 1911, and GSGS 2618 based on a topographic survey of the southern Transvaal during 1910 to 1911. In 1913 the UDF bought a large number of sheets of GSGS 1764 from the British War Office as a precaution against possible German aggression from South West Africa. ${ }^{11}$ The production of GSGS 2230 was seriously impeded by the First World War (1914-1918) and the full series was unavailable until $1929 .{ }^{12}$

After World War I no topographical mapping was undertaken by South Africa and when the UDF was established in 1912, South Africa was entirely dependent on the British War Office for its military intelligence. ${ }^{13}$ This was still the situation in 1914 when the country was subjected to a threatening invasion from German South West Africa, and was called upon to assist in the defence of East Africa. Following World War I, the SA engineering units which served in German South West Africa and Tanganyika were disbanded. ${ }^{14}$

When the South African Trigonometrical Survey Office (TSO) was established in 1921, its first priority was not mapping, but the completion of the primary and secondary triangulation networks of the country. ${ }^{15}$ The country remained unmapped for both military and civilian purposes until 1936 when the situation became so untenable that a high-level decision was taken by government that the TSO should undertake the immediate mapping of the country on a scale of 1:50 000 using aerial photography. ${ }^{16}$ In order to prepare it for its task ahead, the TSO was subjected to a thorough reorganisation, and its staff increased while additional equipment was bought for the implementation of aerial survey techniques. ${ }^{17}$ War was, however, already looming in Europe with the result that 
very few, if any, civilian topographical maps would be published during the ensuing years.

The SA government regarded the provision of reliable maps for military purposes a necessity, and on 7 January 1936, the director of the TSO, William Whittingdale, was appointed ex officio Director of Military Survey of the UDF with the rank of Lieutenant Colonel in the active citizen force (ACF). In the same year, the mapping officer in charge of the new Topographic Branch of the TSO, N Gordon Huntly, was sent on an overseas tour to study both military and civilian mapping and survey methods in the United States and Europe. The tour also included six months at the Ordnance Survey in the United Kingdom, and three months at the British War Office. ${ }^{18}$ On his return, he was appointed assistant director of Military Survey, and on 1 April 1938, under his guidance, the First Field Survey Company was established as an ACF unit.

On 6 September 1939 South Africa declared war on Germany. The mobilisation of the First Field Survey Company had already been ordered in May 1940 before Mussolini had joined forces with Hitler, and during May and June the Company was undergoing training at the Premier Mine east of Pretoria. ${ }^{19}$ On 14 July 1940 the Company, minus the Mapping Group, left South Africa under the command of Majors Walter F. Short and N. Gordon Huntley and, after a road and rail journey of almost $5000 \mathrm{~km}$, reached Nairobi in Kenya on 3 August 1940. They took up quarters at Langata Camp five miles west of Nairobi, but by the end of August moved into The Gables in Sclaters Road, which would become their permanent address until the end of the East African Campaign. ${ }^{20}$ The Mapping Group joined the Company in December $1940 .^{21}$

In February 1941 the establishment of the unit was augmented. It was now called 1 SA Survey Company and consisted of 35 officers, 550 South Africans of diverse cultural origins, and 142 vehicles. $^{22}$

\section{Mapping policy}

In July 1940 and again in November 1940, the following mapping policy decisions regarding East Africa were announced by the Director of Survey of the Middle East operational area: ${ }^{23}$

- The existing 1:2000 000 War Office series (GSGS 2871) would remain the standard map series of Africa with the Union of SA undertaking the maintenance and printing of all sheets south of latitude $4^{\circ} \mathrm{N}$.

- The existing 1:1000 000 series (GSGS 2465), which covered Tanganyika, Kenya and Uganda, had to be extended to include Abyssinia and Somaliland 
as far north as $8^{\circ} \mathrm{N}$. The responsibility for this series would lie with the East African Survey Group (EASG), which was instructed to concentrate mainly on the area of potential operations and movement.

- A 1:500 000 series, which was to consist of sheets compiled on a regular system of sheet lines measuring $2^{\circ}$ each way, covering the whole battle area, would be the standard series for the operational area. The series was to be based on surveys of accessible areas, reconnaissance reports and other map material that could be obtained. Special features were to be photographed from the air.

- A 1:250 000 series of the more developed areas was to be undertaken by 1 SA Survey Company.

- Maps on scales of 1:50 000 and 1:25 000 of selected areas were to be produced by making use of rapid air surveys by 60 SA Air Photographic Squadron.

To understand the complexity of the mapping effort envisaged fully, it is necessary to move forward in time and provide a brief summary of the military operations which took place during the period August 1940 until the Italian East African Army finally surrendered in May 1941.

\section{Abyssinian campaign}

As from June 1940, Italy tested the resolve of the British and Commonwealth forces in northeast Africa.

- On 13 June 1940, Italian forces bombed the Rhodesian air base at Wajir in Kenya;

- On 4 July, the Italians in Eritrea crossed the Sudanese border to capture various Sudanese villages;

- $\quad$ On 3 August 1940 Italian troops invaded and conquered British Somaliland; and

- by December 1940 the Italian forces were firmly established in Eritrea at various strategic points in the Abyssinian Highlands and along the coast of Italian Somaliland at Kismayu and Mogadishu.

The SA forces left South Africa for Kenya in July 1940. Whilst 1 SA Survey Company settled in Nairobi, the $1^{\text {st }}$ SA Division under the command of Lieutenant General George Brink was assembled at its headquarters at Gilgil, northwest of Nairobi. The first British assault on the Italian forces did not involve any SA soldiers. In January 1941 British and Commonwealth troops under General William Platt invaded Italian Eritrea from the Sudan. Agordat was taken on 1 February, and on 27 March 1941 General Platt broke the core of Italian resistance 
in a decisive Allied victory at the Battle of Keren. Asmara surrendered five days later, and Massawa was occupied on 8 April 1941.

The offensive from the south as planned by the British Officer Commanding the East African Force, General Alan Cunningham, was two-pronged - an Allied force should move from Kenya north-east into Italian Somaliland, whilst another force should move north into Abyssinia. The Springboks were involved in both arms of the pincer (see Figure 2). Together with British, West African, East African and Rhodesian troops, the $1^{\text {st }}$ SA Infantry Brigade under Brigadier (later General) Dan Pienaar attacked Somaliland, whilst the $2^{\text {nd }}$ and $5^{\text {th }}$ SA Infantry Brigades under Lt Genl George Brink, assisted by the $25^{\text {th }}$ East African Brigade, struck north to capture the strategic Italian bases of Mega, Yavello, Neghelli and Moyale.

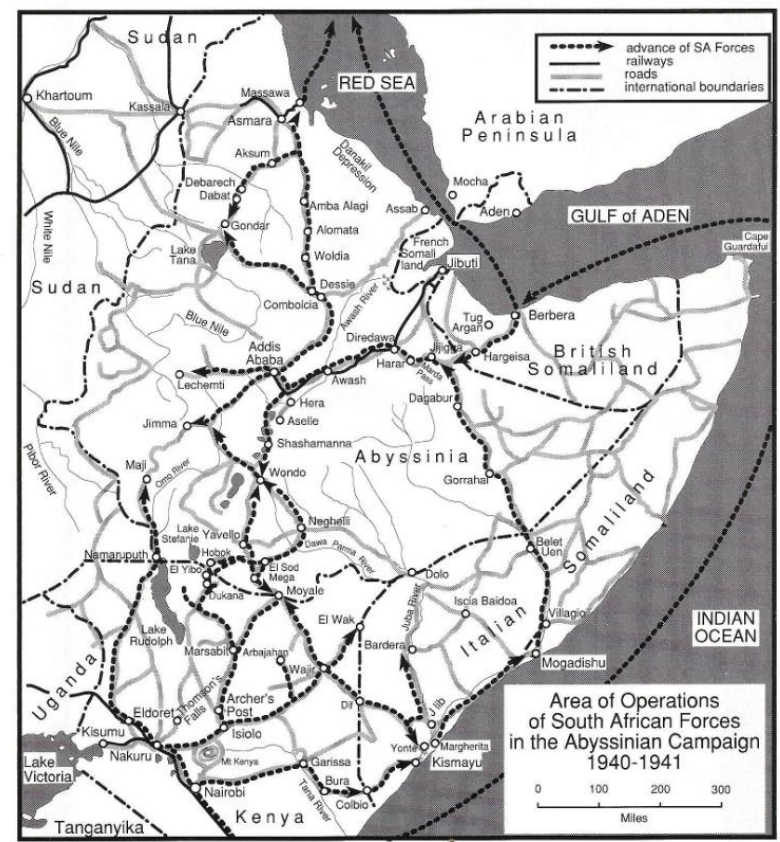

Figure 2. Movement of SA Forces in their attack on Italian East Africa. ${ }^{24}$

To reach the border between Kenya and Abyssinia, and Kenya and Somaliland, the South African and East African forces had to cross Kenya's formidable North Frontier District, a dry and barren wasteland comprising two deserts, namely the soda-sand desert of the Chalbi, stretching northwest of 
Marsabit, and the uninhabitable lava desert, the Dida Galgalla, running north to the Moyale escarpment.

With the average daily temperature well in excess of $110{ }^{\circ} \mathrm{F}\left( \pm 43,4{ }^{\circ} \mathrm{C}\right)$ and no surface water, water supply was a vital challenge. Each soldier received only two gallons ( \pm 7,57 litres) of water per day for personal use, one gallon $( \pm 3,8$ litres) for drinking and the other for washing, bathing and other ablution necessities. ${ }^{25}$ It was in such circumstances that 36 SA Water Supply Company of the SAEC rendered an important service to the Allied forces by drilling water holes and pumping water day and night to keep the military operation going. ${ }^{26}$

The first major offensive took place on 16 December 1940 when the SA $1^{\text {st }}$ Brigade, joined by a battalion from the Gold Coast (now known as Ghana), defeated an Italian unit at El Wak on the Kenya-Somaliland border from where they triumphantly moved to Kismayu on the coast. Further successes were achieved in February 1941 when the SA $2^{\text {nd }}$ and $5^{\text {th }}$ Infantry Brigades together with the East African $25^{\text {th }}$ Infantry Brigade mounted a successful assault on the enemy in southern Abyssinia. The Italian posts at Hobok, El Gumu and Gorai were captured on 2 and 3 February 1941, and on 18 February, the fortress of Mega where the South Africans took 1000 prisoners of war, fell to the Allies. After crossing the Juba River, the Allies moved to Mogadishu, which was captured on 24 February 1941.

With the Italian resistance in Somaliland eliminated, General Cunningham decided to strike immediately north of Mogadishu, following the Italian-built Strada Imperiale across the barren plains of northeastern Abyssinia towards Jijiga and Harar, the latter being the country's second-most important city. The distance of $1200 \mathrm{~km}$ was covered in 17 days. After fierce fighting in the vicinity of Harar and Diredawa, the Allied troops reached the Awash River on 2 April 1941 and on 6 April captured the Abyssinian capital Addis Ababa unopposed. ${ }^{27}$

The war was not yet over. After their defeat by General Platt at the Battle of Keren, the remnants of the Italian-Eritrean Army had fallen back to the southeast towards Dessie and Amba Alagi where they would link up with the defeated armies fleeing north from Addis Ababa. In the meantime, the Emperor of Abyssinia, Haile Selassie, who had lived in exile in Britain since 1936, had returned to his country via the Sudan and had collected an indigenous army called the Shifta, which was now also marching on Addis Ababa and the Italian strongholds at Amba Alagi and Gondar.

The two fiercest battles the South Africans would fight during the entire campaign were in the mountain maze of Dessie and Amba Alagi north of Addis 
Ababa. Towering 10000 feet ( \pm 3050 metres), the peak of Amba Alagi is surrounded by a tumbled maze of mountains and ravines which, in May 1941, was enveloped by biting winds, rain, mist and sleet. On 18 May 1941, after fifteen days of tenacious attack by British, Indian and SA troops, the Duke of Aosta, commander-in-chief of the Italian East African Army formally surrendered with 5000 men. The rainy season postponed the final disbanding of some Italian garrisons which had taken refuge in ancient forts in the mountain country of northwest Abyssinia, but on 27 November 1941 General Nasi, the last of the Italian commanders in the field, surrendered the fortress at Gondar. The war in Abyssinia was over. The total UDF (land) battle casualties in East Africa amounted to 270 of whom 73 were killed. ${ }^{28}$

Apart from 1 SA Survey Company, the other SAEC companies also rendered invaluable service to the Allied Forces throughout the campaign. ${ }^{29}$ Due to the challenge to maintain the country's mines, roads, railroads and public works, the SAEC boasted a large number of engineers who had enlisted for active service and were deployed in East Africa:

- $\quad$ The SA Water Supply Company drilled wells, built water installations and laid pipelines in the dry desert areas of the south whilst the Water Maintenance Company treated large quantities of poor quality water obtained from wells to make it potable.

- $\quad$ The Road Construction and Road Maintenance Companies built roads and passes in rocky and mountainous areas and lay pontoon bridges.

- The Railway Companies built railway lines for the transport of military equipment and troops.

- The Field Sections cleared sites for camps, built base camps and field hospitals, airstrips and landing grounds, and cleared land mines. The SAEC on the whole performed prodigious feats in all theatres of the campaign.

\section{Organisational structure}

1 SA Survey Company was not the only African survey unit which served in East Africa. Other units ${ }^{30}$ were:

- The East African Survey Unit, originally known as the Field Survey Unit King's African Rifles. This unit which was located at Dar es Salaam, consisted of trained surveyors belonging to the Tanganyika Department of lands and Mines. In October 1939 its title was changed to 1 Field Survey Company, East African Engineers;

- The Southern Rhodesian Survey Unit, which was recruited from the staff of the Southern Rhodesia Survey Department and which was based at Nairobi; 
- The West African Survey Unit made up of the Nigerian and Gold Coast (Ghanaian) Survey Departments.

In July 1940 the presence of these divergent survey units and the imminent arrival of the SA Survey Company, made the military authorities in East Africa realise that some form of central survey control was necessary. Two steps were taken to address this situation: ${ }^{31}$

- On 23 July 1940 the Survey Directorate EAF (East African Forces) was established and made responsible for all surveying and mapping in East Africa. Colonel Martin Hotine acted as Deputy Director Survey from November 1940 until February 1941 when he was succeeded by Major JES Bradford of the Southern Rhodesia Survey Company.

- $\quad$ On 1 August 1940 an East African Survey Group (EASG) was formed, which consisted of the East African Survey Unit, the Southern Rhodesian Survey Unit, and the West African Unit. Major JES Bradford of the Southern Rhodesia Survey Company was appointed commander of the group.

1 SA Survey Company was not at any time included in the EASG, but worked as a parallel organisation reporting directly to the Survey Directorate. ${ }^{32} \mathrm{Lt}$ Col. Gordon Huntly, an engineer survey officer in the UDF, was appointed Assistant Director Survey EAF, responsible for the SA troops. Although not officially a member of the Survey Directorate EAF, he served as de facto member until April 1941 when he left to take up a post in the Survey Directorate, GHQ (General Headquarters), Middle-East Command.

To facilitate the distribution of survey, photographic and cartographic information and data to the various units, three central offices were established which operated under the technical control of the Survey Directorate EAF: the Central Trigonometrical Records (CTS), the Central Photographic Records (CPR), and the Central Cartographic Records (CCR). ${ }^{33}$

\section{Photographic Squadron, SAAF}

The size of the potential battle area and the fact that the surveyors could only work to a very limited extent in enemy territory made it apparent from early on that air survey methods would be of the utmost importance. On 1 January 1940 the Commander of the SA Defence Force, General Pierre van Ryneveld, received 
the following urgent message from the Commander of the British Force in East Africa, Lieutenant General (Lt Gen.) Alan Cunningham:

Situation EAST AFRICA photographic aircraft for mapmaking is desperate. Three Ansons unserviceable for lack of spares. One Anson and Double Eagle due for major overhaul. NO other aircraft available for map photography. Mapmaking urgent necessity in view of projected operations. Can you possibly help? ${ }^{34}$

The task to photograph large areas of East Africa for mapping purposes fell to 1 Survey (Flight) of 60 Photographic Squadron of the South African Air Force (SAAF). The Squadron initially flew Airspeed Envoy aircraft, which were later replaced by Ansons. The operational instructions given to this flight were to take photographs of the areas required by the Survey Directorate, to develop the films and to produce contact prints, which were then handed over to the Photo-Topo Sections of the EASG and 1 SA Survey Company. Personnel of the squadron were attached to the latter unit to form a photo developing and printing section.

With only a few aircraft and limited resources at their disposal, the pilots, ground staff and photographic personnel produced valuable and urgently required photography on an ongoing basis. ${ }^{35}$

\section{Activities of groups and sections}

Commanded by Major Walter F Short, 1 SA Survey Company comprised the following groups: ${ }^{36}$

- Field sections;

- A geodetic section;

- A map production group;

- A photo-topo group;

- A map reproduction group; and

- An instrument repair section.

Five sections of 1 SA Survey Company operated in the field, each consisting of four officers, 12 other ranks and 20 to 30 local African labourers. In addition to these, survey parties were also attached to the $1^{\text {st }}$ South African Division and the $25^{\text {th }}$ EA Infantry Brigade at Marsabit. The operational orders to the field sections were, if time permitted, to -

- Continue the existing Kenya primary triangulation northwards into southeastern Abyssinia to be connected to the Uganda triangulation; 
- $\quad$ Establish a secondary and minor triangulation network to provide control points for artillery purposes and subsequent aerial photographic surveys;

- $\quad$ Map large areas by ground methods (plane tabling) for road building and other infrastructure purposes;

- $\quad$ Check the topography on existing captured maps;

- $\quad$ Prepare sketch maps from aerial photographs; and

- Maintain the records of the surveys undertaken (see Figure 3).

The triangulation required thorough reconnaissance exercises, night observation to attain good visibility (no mirage or glare), and stable conditions (no wind), baseline measurement and beacon building. Many points were inaccessible by vehicle and necessitated long safaris on foot through dense bush and over boulder-covered ground.

The lack of water was an ongoing problem, and a certain amount of bush cutting was necessary to clear lines of sight. The plane table mapping was done on a scale of 1:100 000 with contour intervals of 250 foot (approximately $60 \mathrm{~m}$ ), and it was required to fix the position of all roads, buildings, villages, boreholes, permanent water holes and military positions. The country was generally difficult to access as large areas were covered by an extensive lava sheet consisting of jagged and loose boulders in an endless series of shallow hollows and mounds.

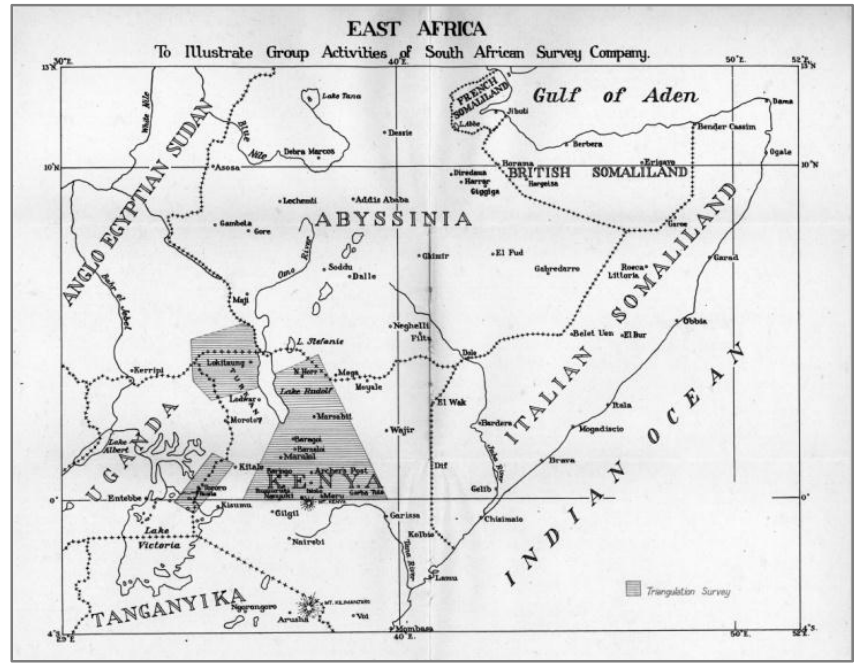

Figure 3. Triangulation surveys by 1 SA Survey Company, 1940-41.37 
The information collected by the surveyors in the field was passed on to the photo-topo and map production sections, which were responsible for the transfer of topographical information from aerial photographs to plane tables, and for the actual compilation and fair drawing of the maps. The members of the SA PhotoTopo Group were mostly drawn from the staff of the Topographical Survey Office (TSO) in South Africa and were therefore trained in topographical work. Altogether 74 members of the TSO were recruited for active service from 1939 to 1945 and most of the technical and transport equipment used by 1 SA Survey Company was provided by the TSO. ${ }^{38}$ The Map Production Group consisted of volunteers from various government departments and municipal and private drawing offices in the Union of South Africa. Although trained draughtsmen, they had very little mapping experience and no knowledge of reproductive methods used in cartography. After being trained in map production methods, they worked in shifts of 10 hours on and 20 hours off, and produced roughly three to five maps per day. Every effort was made to issue maps at least one jump ahead of the troops, but movement was so rapid that it sometimes became necessary to stop work on those maps of an area already covered, to jump ahead of the troops once more.

Throughout the campaign map reproduction was concentrated in Nairobi. ${ }^{39}$ The EA Survey Group had a hand-operated map printing plant at its disposal to which additional equipment was supplied in October 1940 from the Middle East Command. In the Union of South Africa, the lithographic printing of peacetime topographical maps was not, as in most other countries, undertaken by the TSO, but by the Government Printer. On mobilisation, the Government Printer became the UDF Director of Army Printing and Stationery Supplies (DAP \& SS). The DAP \& SS soon formed a Mobile Printing Company which in 1940 was moved to Nairobi to be attached to 1 SA Survey Company. The printing work was divided between the EASG and 1 SA Survey Company, and although some sheets were compiled, drawn and printed by only one of these units, many were compiled and drawn by the one and printed by the other.

\section{Maps produced}

1 SA Survey Company was involved in the production of the following maps and map series:

\section{Strip maps on variable scales compiled directly from aerial photographs}

The provision of sketch maps, which were constantly and urgently required by the troops for day-to-day operations, was high on 1 SA Survey Company's list 
of priorities. The aerial photographs were taken by 60 Photographic Squadron, SAAF which played a vital part in the campaign, and whose contribution in providing photographs for map production was of the highest order. The maps were required whenever the troops were faced with an enemy defence position and the prospect of a battle, or when some special topographical feature, such as a river or bridge, lay ahead. Producing the relevant maps required the utmost co-operation between the photographic staff, the photo-topo sections who did the compilation and drawing, and the printing sections who often worked continuously for 48 hours to produce maps for an urgent operation in a minimum of time. ${ }^{40}$

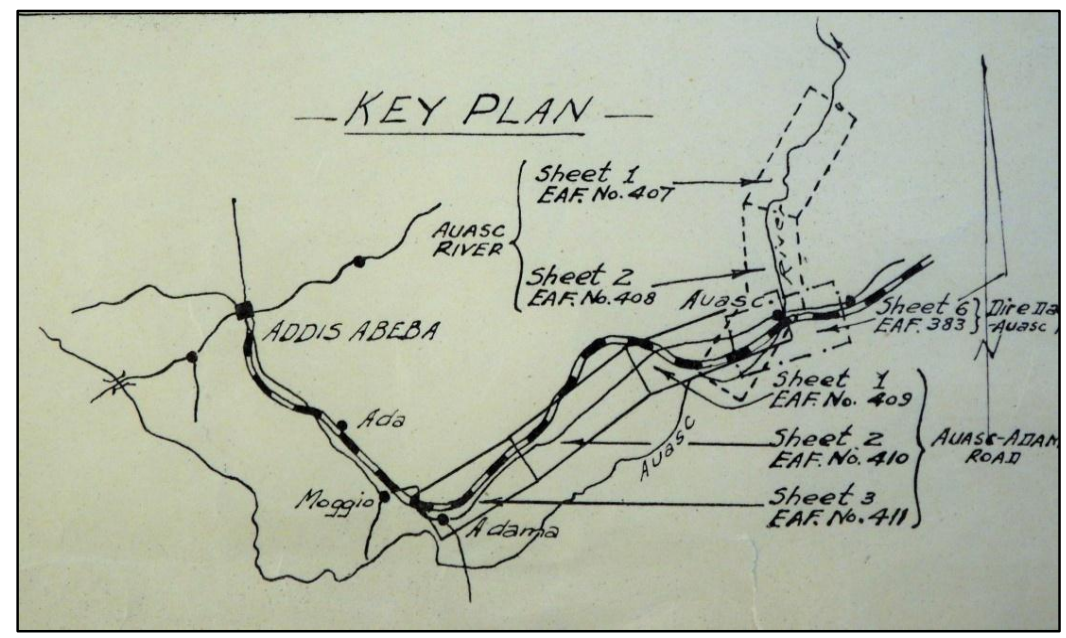

Figure 4. Diagram showing the position of the six map sheets covering the road east of Addis Ababa. ${ }^{41}$

The author has located 48 strip map sets on variable scales in the British Library (see Table 1), some of which comprise one or two map sheets, whereas others comprise 5, 6 or even 19 map sheets to adequately cover the relevant problem area (see Figures 4 and 5). The centres or principal points of the aerial photographs used for each strip are indicated on the maps. The information gathered from these maps differs in some respects from the list provided in Appendix B of Visick's History of the SA Survey Company. ${ }^{42}$ 


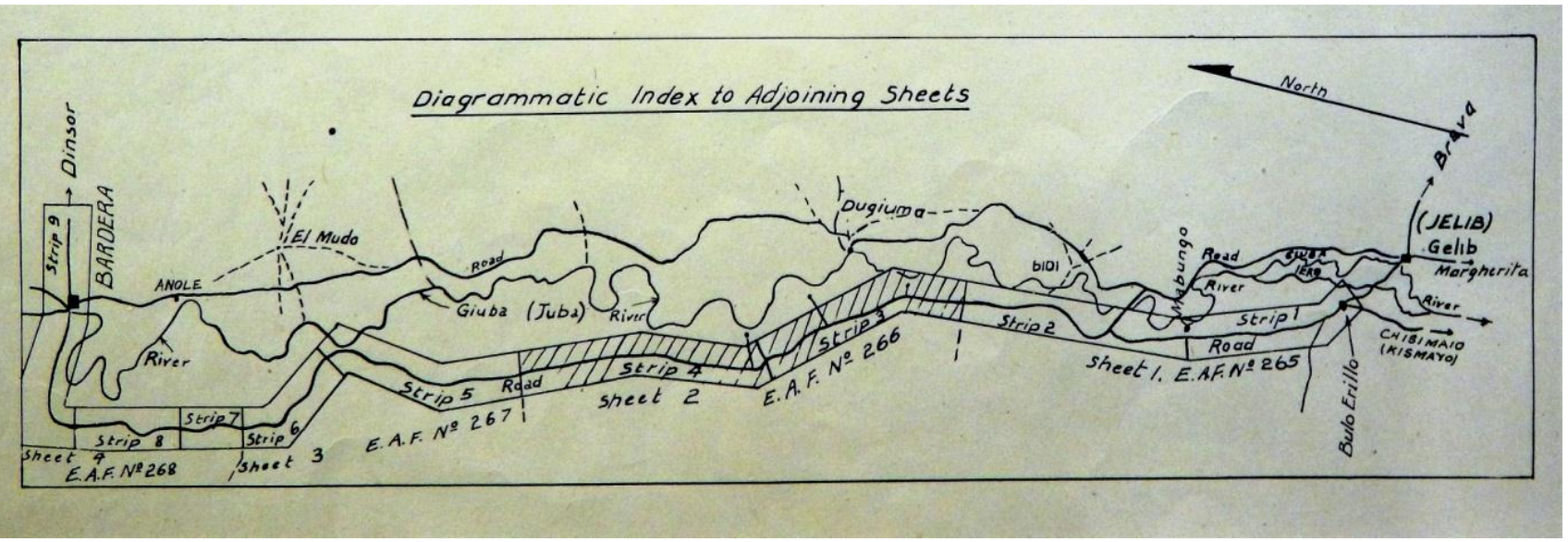

Figure 5. Diagram showing the position of the four map sheets covering the road between Gelib and Bardera west of the Juba River. $^{43}$ 


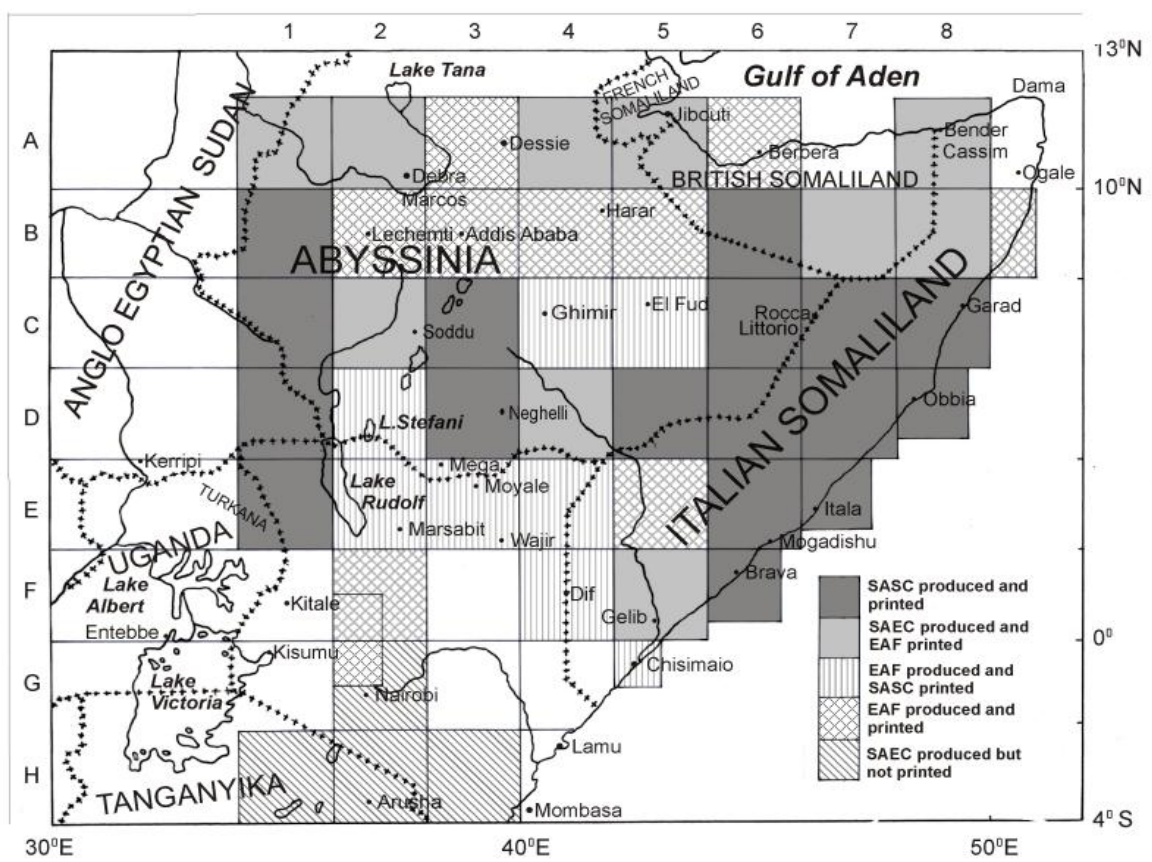

Figure 6 1:500 000 mapping by 1 SA Survey Company and the East African Survey Group, 1940-41. (The row of figures at the top (X-axis) and the column of letters on the left (Y-axis) are by the author and have no relevance to the actual titles of the map sheets which are listed in Table 2 
East Africa $1: 500000$ series

The East Africa 1:500 000 series was compiled on the Transverse Mercator Projection based on the Clarke 1880 spheroid. ${ }^{44}$ Of the 62 sheets which covered the entire battle, only 47 could be found in South Africa. ${ }^{45}$ On examining the actual map sheets, it was not always possible to determine which maps were published for the first time during the campaign and which after the campaign. The index map in a relevant official UDF publication ${ }^{46}$ was also found to be incomplete, as it does not show all the sheets which were identified, nor does it differentiate between the work of 1 SA Survey Company and the EASG. In this article, Figures 6 and 8 attempt to address this problem by depicting the first edition and first printing of the various sheets produced by each of these units during the period December 1940 to May 1941. Due to the sharing of responsibilities by the SAEC and the EASG, the second or third edition of a sheet issued by a particular unit was later often produced by the alternative unit with a corresponding change in appearance. After May 1941, the 1:500 000 series became the sole responsibility of the EASG.

A

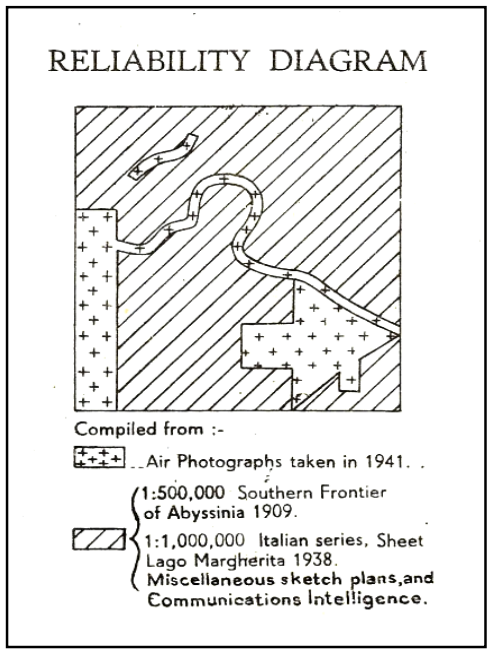

B

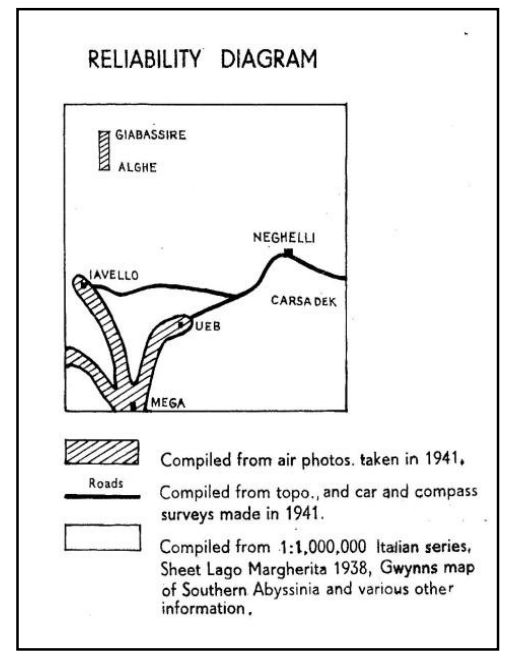

\section{Figure 7}

A: Reliability diagram of 1: 500000 sheet Gabredarre

B: Reliability diagram of 1: 500000 sheet Neghelli

As most maps had to be compiled from information collected by the field sections and whatever other sources were available, many sheets carry a 'reliability 
diagram', announcing that "This map is compiled from the best available information. Surveys on the ground have not been made and the map may be unreliable." ${ }^{47}$ Some sheets, however, show reliability diagrams giving more exact information regarding the actual sources used (see Figures 7A and 7B).

The 1:500 000 maps of East Africa produced by 1 SA Survey Company were published in either three or four colours. The style and appearance of the maps closely resemble the South Africa UDF 1:250 000 series which was to be produced by 45 Survey Company, SAEC, upon the latter's return to the Union in $1942 .^{48}$

East Africa $1: 125000$ series

The coverage of the 1:125 000 map series produced by 1 SA Survey Company during the campaign is shown in Figure 8.

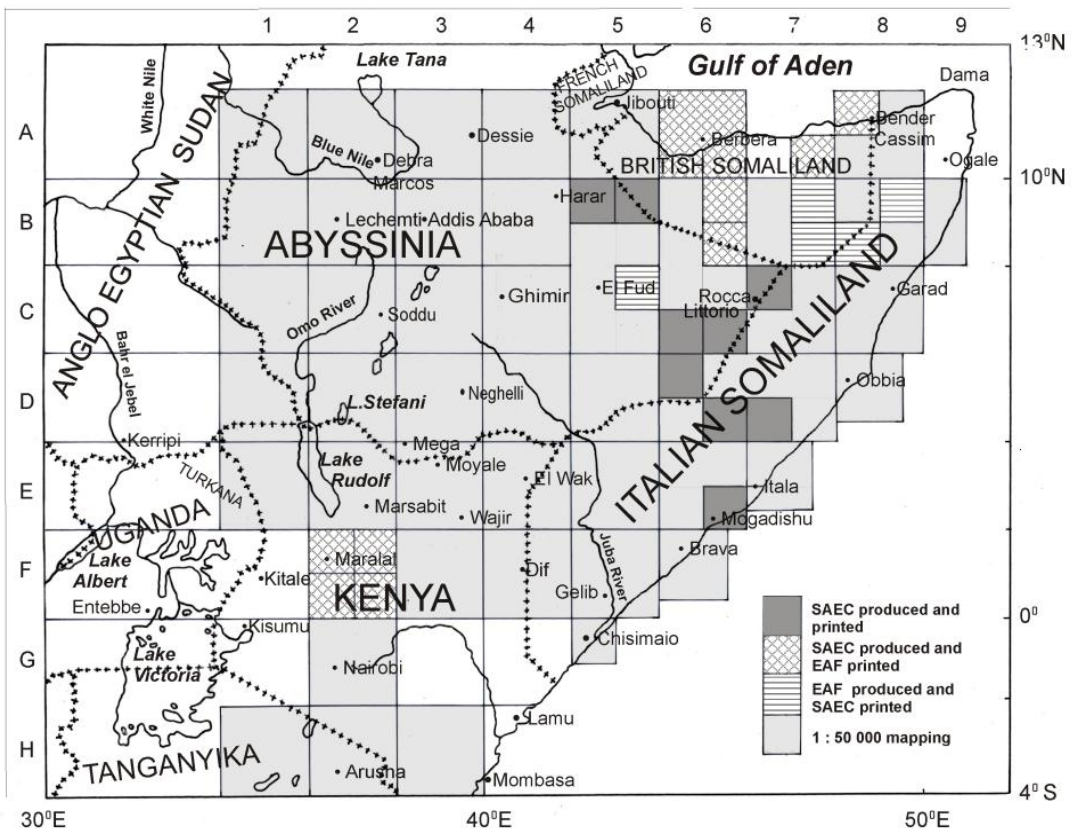

Figure 8 1:250 000 mapping by 1 SA Survey Company and the East African Survey Group, 1940-41. 
Africa 1: 2000000 series

GSGS 2871 south of $4^{\circ} \mathrm{N}$ (see Figure 9). This task involved a complete revision and redrawing of the existing maps by the TSO and the SA maps were published as UDF 656. The first edition (1940) appeared in black and white only, with blue hydrographical features, but in 1943, a new edition with layer tinting for altitudes was published.

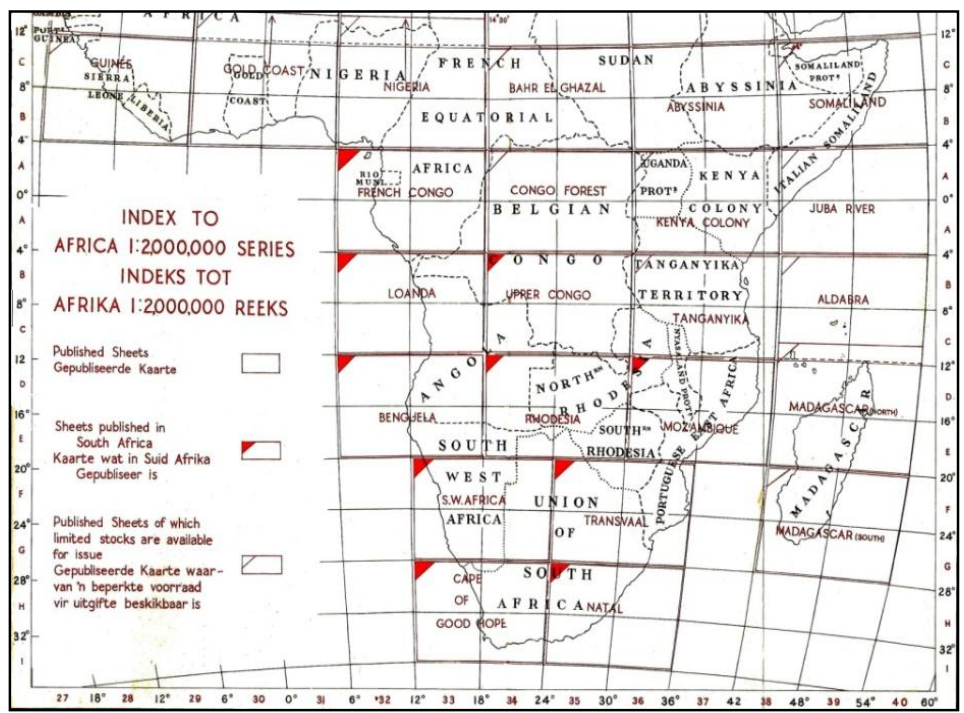

Figure 9 Sheets of the Africa 1:2 000000 map series produced and printed in South Africa. ${ }^{49}$

\section{Gazetteer}

In May 1941, 1 SA Survey Company was moved to the Middle East with all its equipment and personnel, including the attached lithographic section. Before leaving Nairobi, the Company had completed a gazetteer to enable place names to be located on the 1:500 000 map series. ${ }^{50}$ The gazetteer contained over 23000 place names, for which grid references were provided. The compilation took approximately 3000 man-hours in addition to a further 600 man-hours for subsequent checking. ${ }^{51}$ 


\section{Final war-time deployment}

In May 1941, 1 SA Survey Company was moved to Egypt to serve in the Western Desert. On 2 April 1942, the Company was split into two units: A type 'A' unit, now called 45 Survey Company, was returned to South Africa under the command of Lt Col. WF Short, with 13 officers and 103 other ranks. A type 'B' company was retained as the operational field unit, re-designated 46 Survey Company, SAEC, with 25 officers and 240 other ranks, and assigned to the (British) $8^{\text {th }}$ Army. In August 1943, after the conclusion of the North African Campaign, 46 Survey Company was reorganised in Cairo, and on 14 August 1943, prior to the invasion of Italy, reassigned to the $5^{\text {th }}$ US Army at Tripoli. Whilst serving in Italy, 46 Survey Company, SAEC was twice awarded the $5^{\text {th }}$ Army plaque for excellence in discipline, performance and merit. ${ }^{52}$

\section{Conclusion}

From their inception, maps have been used for military purposes. As the result of previous intelligence-gathering, reconnaissance and surveying, they provide military commanders with a two-dimensional model of the country over which operations are envisaged, and this model enables the planning of marches, of strategy, and of operations of all kinds. Without this picture of the theatre of operations constantly at hand, together with a knowledge of the enemy's dispositions and a view of his intentions, it is all but impossible for a military commander to manoeuvre with security.

During their 10 months' stay in East Africa, the members of 1 SA Survey Company proved that by using survey data and aerial photographs they could produce reliable maps without delay so that when the frontline men went into action they were continuously supplied with maps that were sufficiently detailed for operational planning. Much of the success of the Company was due to the fact that many of its members were experienced geodetic surveyors, topographers and map production officers who had trained at the TSO or the gold mines back in South Africa. ${ }^{53}$ The officers in charge could also count on the specialised skills and knowledge of competent draughtsmen and instrument repairers whereas the mobile printing unit was but a branch of the South African Government Printer. ${ }^{54}$ Albeit under extreme circumstances, 1 SA Survey Company served South Africa with distinction in East Africa and could take its place with pride amongst the other survey units of the Allies with which it was to continue serving until the end of the War. 


\begin{tabular}{|c|c|c|c|c|c|}
\hline & Title of map & Scale & $\begin{array}{l}\text { Number } \\
\text { of sheets }\end{array}$ & Size of one sheet & $\begin{array}{l}\text { Shelf mark in British } \\
\text { Library }\end{array}$ \\
\hline 1 & Mogadiscio (Magadishu) & 1: 25000 & 2 & $83 \times 52 \mathrm{~cm} \mathrm{P}$ & Maps MOD EAF 189 \\
\hline 2 & Lower Giuba (Juba) & 1: 25000 & 19 & $82 \times 55 \mathrm{~cm} \mathrm{P}$ & Maps MOD EAF 192-210 \\
\hline 3 & Mega Approaches & 1: 50000 & 1 & $87 \times 53 \mathrm{~cm} \mathrm{P}$ & Maps MOD EAF 167 \\
\hline 4 & Harar-Irna Road & 1: 20000 & 4 & $88 \times 55 \mathrm{~cm} \mathrm{P}$ & Maps MOD EAF 403-406 \\
\hline 5 & Dire Daua - Ausc Road & $1: 25000$ & 6 & $88 \times 57 \mathrm{~cm} \mathrm{P}$ & Maps MOD EAF 378-383 \\
\hline 6 & Ausc-Adama Road & 1: 26400 & 3 & $88 \times 57 \mathrm{~cm} \mathrm{P}$ & Maps MOD EAF 380 \\
\hline 7 & Brava-Mogadiscio (Mogadishu) & 1: 37000 & 5 & $87 \times 57 \mathrm{~cm} \mathrm{P}$ & Maps MOD EAF 243-247 \\
\hline 8 & $\begin{array}{l}\text { Amar Cocche (Amar Koke) Murle- } \\
\text { Shunguru Road }\end{array}$ & 1: 50000 & 2 & $88 \times 55 \mathrm{~cm} \mathrm{P}$ & Maps MOD EAF 226-227 \\
\hline 9 & Ausc & $1: 25000$ & 5 & $87 \times 54 \mathrm{~cm} \mathrm{P}$ & Maps MOD EAF 407- \\
\hline 10 & El Dokolle Area & $1: 50000$ & 2 & $57 \times 85 \mathrm{~cm} \mathrm{~L}$ & Maps MOD EAF 165-166 \\
\hline 11 & Belecta-Harar (South) Road & $1: 23000$ & 1 & $87 \times 55 \mathrm{~cm}$ & Maps MOD EAF 402 \\
\hline 12 & Neghelli & $1: 6000$ & 1 & $40 \times 74 \mathrm{~cm} \mathrm{~L}$ & Maps MOD EAF 231 \\
\hline 13 & Bura & $1: 25000$ & 4 & $88 \times 56 \mathrm{~cm} \mathrm{P}$ & Maps MOD EAF 271-274 \\
\hline 14 & Garissa & $1: 25000$ & 4 & $87 \times 55 \mathrm{~cm} \mathrm{P}$ & Maps MOD EAF 217-220 \\
\hline 15 & El Sod & $1: 16500$ & 1 & $57 \times 85 \mathrm{~cm} \mathrm{~L}$ & Maps MOD EAF 159 \\
\hline 16 & Dubuluch & $1: 16300$ & 1 & $55 \times 85 \mathrm{~cm} \mathrm{~L}$ & Maps MOD EAF 160 \\
\hline 17 & Mogadiscio & $1: 14300$ & 1 & $55 \times 85 \mathrm{~cm} \mathrm{~L}$ & Maps MOD EAF 189 \\
\hline 18 & Gorrahei-Sassabaneh Road & $1: 25000$ & 1 & $56 \times 83 \mathrm{~cm} \mathrm{~L}$ & Maps MOD EAF 338-342 \\
\hline 19 & Addis Abeba (Addis Ababa) & $1: 25000$ & 2 & $57 \times 85 \mathrm{~cm} \mathrm{~L}$ & Maps MOD EAF 371-372 \\
\hline 20 & Galma Galla - Kolbio Road & $1: 50000$ & 1 & $55 \times 86 \mathrm{~cm} \mathrm{~L}$ & Maps MOD EAF 115 \\
\hline 21 & El Gumu & $1: 20000$ & 1 & $55 \times 85 \mathrm{~cm} \mathrm{~L}$ & Maps MOD EAF 152 \\
\hline 22 & G. Gianciaro \& Environs & $1: 25000$ & 1 & $54 \times 87 \mathrm{~cm} \mathrm{~L}$ & Maps MOD EAF 153 \\
\hline 23 & Ririba River & $1: 25000$ & 1 & $88 \times 55 \mathrm{~cm} \mathrm{P}$ & Maps MOD EAF 154 \\
\hline 24 & Dif - Afmadu Road & $1: 26400$ & 1 & $55 \times 85 \mathrm{~cm} \mathrm{~L}$ & Maps MOD EAF 155 \\
\hline 25 & Mega - Ueb Road & $1: 37000$ & 1 & $60 \times 88 \mathrm{~cm} \mathrm{~L}$ & Maps MOD EAF 181 \\
\hline 26 & Liboi - Afmadu Road & $1: 50000$ & 1 & $55 \times 88 \mathrm{~cm} \mathrm{~L}$ & Maps MOD EAF 186 \\
\hline
\end{tabular}




\begin{tabular}{|c|c|c|c|c|c|}
\hline 27 & Afmadu-Gelib Road & $1: 25000$ & 1 & $6 \times 88 \mathrm{~cm} \mathrm{~L}$ & Maps MOD EAF 187 \\
\hline 28 & Auasc River Crossing \& Env. & $1: 50000$ & 2 & $56 \times 86 \mathrm{~cm} \mathrm{~L}$ & Maps MOD EAF 384 \\
\hline 29 & Bura - Galma Galla Road & $1: 50000$ & 1 & $86 \times 55 \mathrm{~cm} \mathrm{P}$ & Maps MOD EAF 110 \\
\hline 30 & Afmadu - Soia Road & $1: 50000$ & 1 & $48 \times 84 \mathrm{~cm} \mathrm{~L}$ & Maps MOD EAF 158 \\
\hline 31 & Liboi - Soia Road & $1: 50000$ & 2 & $55 \times 85 \mathrm{~cm} \mathrm{~L}$ & Maps MOD EAF $156-15 ?$ \\
\hline 32 & Garissa -Liboi Road & $1: 50000$ & 2 & $55 \times 86 \mathrm{~cm} \mathrm{~L}$ & Maps MOD EAF 106-10? \\
\hline 33 & Bulo Erillo - Bardera Road & $1: 39500$ & 4 & $85 \times 54 \mathrm{~cm} \mathrm{P}$ & Maps MOD EAF 265-268 \\
\hline 34 & Giggiga - Harar Road & $1: 10000$ & 4 & $55 \times 88 \mathrm{~cm} \mathrm{~L}$ & Maps MOD EAF 385-38 \\
\hline 35 & G. Gorai & $1: 21000$ & 1 & $55 \times 46 \mathrm{~cm} \mathrm{P}$ & Maps MOD EAF 141 \\
\hline 36 & Dagamedo - Harar Road & $1: 25000$ & 2 & $55 \times 86 \mathrm{~cm} \mathrm{~L}$ & Maps MOD EAF 400-401 \\
\hline 37 & $\begin{array}{l}\text { G. Ganciaro - Meti Amar \& } \\
\text { Cocche (Amar Koke) Road }\end{array}$ & $1: 50000$ & 1 & $55 \times 88 \mathrm{~cm} \mathrm{~L}$ & Maps MOD EAF 191-225 \\
\hline 38 & Ueb \& Environs & $1: 50000$ & 1 & $88 \times 57 \mathrm{~cm} \mathrm{P}$ & Maps MOD EAF 182 \\
\hline 39 & Dubuluch - Iavello Road & $1: 50000$ & 2 & $88 \times 55 \mathrm{~cm} \mathrm{P}$ & Maps MOD EAF 183-18 \\
\hline 40 & Portion of Auasc River & $1: 28800$ & 2 & $57 \times 88 \mathrm{~cm} \mathrm{~L}$ & Maps MOD EAF 408-40 \\
\hline 41 & Auasc River Crossing & $1: 10000$ & 1 & $57 \times 44 \mathrm{~cm} \mathrm{P}$ & Maps MOD EAF 376 \\
\hline 42 & Mogadiscio (Mogadishu) & $1: 14300$ & 1 & $55 \times 88 \mathrm{~cm} \mathrm{~L}$ & Maps MOD EAF 189 \\
\hline 43 & Waji - Dif Road & $1: 50000$ & 1 & $55 \times 87 \mathrm{~cm} \mathrm{~L}$ & Maps MOD EAF 108-10 \\
\hline
\end{tabular}

Table 1. Strip maps prepared directly from aerial photographs flown by 60 Photographic Squadron, SAAF.

(Orientation: $\mathrm{P}$ = portrait; $\mathrm{L}=$ landscape). 


\begin{tabular}{|c|c|c|c|}
\hline & $\begin{array}{c}\text { Title of 1: } 500000 \\
\text { map sheets }\end{array}$ & & $\begin{array}{c}\text { Title of 1: } 500000 \\
\text { map sheets }\end{array}$ \\
\hline A1 & Asosa & E1 & Moroto \\
\hline A2 & Debra Marcos & Lo & 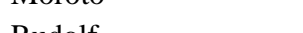 \\
\hline $\mathrm{A} 3$ & Dessie & $\mathrm{E} 2$ & Rudolf \\
\hline A4 & Abbe & E3 & Moyale \\
\hline A5 & Djibouti & E4 & El Wak \\
\hline A6 & Berbera & E5 & Bardera \\
\hline A7 & Erigano & E6 & Mogadiscio \\
\hline A8 & Bender Cassim & E7 & Itala \\
\hline B1 & Gore & E8 & - \\
\hline B2 & Lechemiti & & \\
\hline B3 & Addid Abeba & $\mathrm{F} 1$ & \\
\hline B4 & Dire Daua & F2 & Maralal \\
\hline B5 & Harrar & F3 & Garba Tula \\
\hline B6 & Odweina & F4 & Dif \\
\hline B7 & Yagare & F5 & Gelib \\
\hline B8 & Halin & $\begin{array}{l}\Gamma J \\
\text { F6 }\end{array}$ & Brava \\
\hline B9 & Bender Beila & F7 & - \\
\hline $\mathrm{C} 1$ & Magai & F8 & - \\
\hline $\mathrm{C} 2$ & Soddu & & \\
\hline $\mathrm{C} 3$ & Dalle & G1 & Ramaruti \\
\hline $\mathrm{C} 4$ & Ghimir & $\mathrm{G} 2$ & Suna \\
\hline C5 & El Fud & G3 & \\
\hline C6 & Gabredarre & Us & \\
\hline C7 & Roca Littorio & G4 & Kolbio \\
\hline $\mathrm{C} 8$ & Garad & G5 & Chisimaio \\
\hline & & G6 & - \\
\hline D1 & Lokitaung & G7 & - \\
\hline D2 & Stephanie & G8 & - \\
\hline D3 & Neghelli & & \\
\hline D4 & Filtu & & \\
\hline D5 & Dolo & $\mathrm{Hl}$ & - \\
\hline D6 & Bellet Uen & $\mathrm{H} 2$ & - \\
\hline D7 & El Bur & $\mathrm{H} 3$ & Garissa \\
\hline \multirow[t]{5}{*}{ D8 } & Obbia & $\mathrm{H} 4$ & - \\
\hline & & H5 & - \\
\hline & & H6 & - \\
\hline & & $\mathrm{H} 7$ & - \\
\hline & & $\mathrm{H} 8$ & - \\
\hline
\end{tabular}

Table 2. Titles of 1:500 000 map sheets (to be read in conjunction with Figure 3). 


\section{ENDNOTES}

${ }^{1}$ Professor E. C. Liebenberg is Emeritus Professor of Geography, University of South Africa.

${ }^{2}$ I van der Waag. A military history of modern South Africa. Johannesburg: Jonathan Ball, 2015, p. 185.

${ }^{3}$ Ibid., p. 185; EGM Alexander. "The participation of the South African Forces in the II World War". Typescript monograph, May 1985. SANDF Documentation Centre Library A3551, Pretoria, p. 6.

${ }^{4} \mathrm{~N}$ Orpen \& HJ Martin. Salute the Sappers: The formation of the South African Engineer Corps and its operations in East Africa and the Middle East to the Battle of Alamein. Vol. 2, Part 1. Johannesburg: Sappers Association, 1981, 16; A Wessels. "Die opbou van die UVM in die tydperk September 1939September 1941". Joernaal vir Eietydse Geskiedenis 19/3. December 1994, pp.16-19.

${ }^{5}$ AB Clough. Maps and survey. London: War Office, 1952, p. 151.

${ }^{6}$ Ibid. pp. 136, 204.

${ }^{7}$ Clough op. cit., p. 151; Geographical Section, General Staff. Catalogue of maps. London: War Office, 1930.

${ }^{8}$ EC Liebenberg. "Die topografiese kartering van Suid-Afrika, 1879-1972". Unpublished MA dissertation, University of South Africa, Pretoria, 1974.

${ }^{9}$ E Liebenberg. "Mapping for Empire: British military mapping in South Africa, 1806-1914". In E Liebenberg, I J Demhardt \& S Vervust (eds.), History of military cartography, Heidelberg: Springer, 2016.

${ }^{10}$ E Liebenberg. "Mapping British South Africa: The case of GSGS 2230". Imago Mundi 49. 1997. pp. 129-142.

${ }^{11}$ SANDF Documentation Centre, Pretoria. DC, Group 2, Box 150. GSGS, War Office to High Commissioner, Union of South Africa, 5 November 913.

${ }^{12}$ Ibid., p. 140.

${ }^{13}$ IJ van der Waag. "Major J.G.W. Leipoldt, DSO: A portrait of a South African Surveyor and Intelligence Officer, 1912-1923". Militaria 25/1. 1955, 22.

${ }^{14}$ Clough op. cit., p. 531.

${ }^{15}$ Liebenberg, "Die topografiese kartering ..." op. cit., pp. 301-310.

${ }^{16}$ National Geo-Information, TSO D.217. "Annual Report of the Director of the Trigonometrical Survey Office, 1937". Unpublished typescript document.

${ }^{17}$ Liebenberg, "Die topografiese kartering ..." op. cit., p. 344.

${ }^{18}$ FWM. "Obituary. Commandant GRNC Huntly, OBE, ED". SA Survey Journal 8/48. December 1952, pp 4-5.

${ }^{19}$ Orpen \& Martin op. cit., p. 21.

${ }^{20}$ DL Visick. History of the South African Survey Company, SAEC in East Africa from July, 1940 to June, 1941. Pretoria: UDF, ca. 1945, pp. 5-6.

${ }^{21}$ UWH. NAREP EA, 160. "Units and formations. Short history of SA Military Survey Service, 1918-1945". Unpublished typescript document, SANDF Documentation Centre, Pretoria, pp. 4-5.

${ }^{22}$ Ibid., p .5. 
${ }^{23}$ Clough op. cit., p. 153.

24 JA Brown. The war of a hundred days. Johannesburg: Ashanti, 1990.

25 UWH. NAREP EA, 125. "Report on medical services in East-Africa, Italian

Somaliland \& Abyssinia". Unpublished typescript document, SANDF Documentation Centre, Pretoria, p. 31.

${ }^{26}$ Orpen \& Martin op cit., pp. 40, 129-130.

27 A Wessels. "Die aanwending van die Unie-Verdedigingsmagte in die tydperk September 1939 tot September 1941". Joernaal vir Eietydse Geskiedenis 19/3. 1995. pp. 13-17.

${ }^{28}$ RJ Bouch. Infantry in South Africa. Documentation Service SADF, Pretoria, 1977, p. 145.

${ }^{29}$ Alexander op. cit., p. 10.

${ }^{30}$ Clough op. cit., pp. 141-142.

${ }^{31}$ Ibid., pp. 145-146.

32 Ibid., p. 145.

33 Ibid., p. 154.

34 SANDF Documentation Centre Library, Pretoria, A. 3923. "The East African Campaign, SA Forces, July 1940 to July 1941”. Unpublished typescript report, p. 24.

${ }^{35}$ Clough op. cit., pp. 144-145.

${ }^{36}$ Visick op. cit., p. 6; A Jacobs \& H Smit. "Topographic mapping support in the South African Military during the $20^{\text {th }}$ century". Scientia Militaria 32/1, 2004. 39-41.

37 Visick op. cit.,

${ }^{38}$ South Africa, Department of Land Affairs. The Chief Directorate: Surveys and Mapping. 80 years of surveying and mapping South Africa. Cape Town: Chief-Directorate: Surveys and Mapping, 2000, 90.

${ }^{39} \mathrm{G}$ McGrath. The surveying and mapping of British East Africa 1890 to 1946. Origins, development and coordination. Monograph no. 18/1976. Toronto: Department of Geography, York University, 1976, 100.

${ }^{40}$ Clough op. cit., pp. 157-158.

${ }^{41}$ British Library, Ausc River - sheet no 2, scale 1:28 800 (approx.)Compiled from Air Photograophs raken on 20 March 1941 by 14 \& 64 Sqdns, SAAF. Drawn and Printed by S.A. Survey Company, March 1941.

${ }^{42}$ Visick op. cit., pp. 61-64.

${ }^{43}$ British Library, Bulo Erillo - Bardera Road, sheet no 1, scale $1: 39500$ (approx.) Compiled from Air Photography taken on 20 Feb 1941 by 14 and 60 Sqdns, SAAF. Drawn and Printed by S.A. Survey Company, Feb. 1941.

${ }^{44}$ Clough op. cit., p160.

${ }^{45}$ GSGS, War Office. Interim Catalogue of Maps. London: War Office, 1947, 14. The map collections of two institutions in South Africa were visited: The SANDF Documentation Centre, Pretoria, and the Ditsong Museum of Military History, Johannesburg. Both hold incomplete sets of the East African $1: 500000$ series.

${ }^{46}$ Visick op cit. 
47 This note appears on almost all the maps listed in Table 1.

${ }^{48}$ By 1942 a Japanese threat had necessitated some provision for the defence of the Union of South Africa. The largest scale map completely covering the Union at that stage was the so-called Irrigation Map on a $1: 500000$ scale, which was inadequate for military purposes. In 1942, 45 Survey Company was returned to South Africa from Egypt to carry out a crash mapping programme on a scale of $1: 250000$ of a belt of approximately $250 \mathrm{~km}$ wide around the entire South African coast from Mozambique to Angola (see Orpen \& Martin op. cit., p. 323).

${ }^{49}$ Survey Directorate, Union Defence Force. Catalogue of Maps published in the Union of South Africa. Pretoria: Union Defence Force, 1944, p. 23.

${ }^{50}$ Visick op. cit., pp. 53-54.

${ }^{51}$ Clough op. cit., p. 157.

52 SANDF Documentation Centre, Pretoria. UWH. NAREP 160. "Units and formations ..." op. cit., p. 9. See also MA Simenhoff. "The unit history of 46 Survey Squadron SAEC (CF)". Unpublished report, revised by FP le Roux. Cape Town: Chief-Directorate of Surveys and Mapping, 2003.

53 JA Brown, op. cit., 70.

${ }^{54}$ Clough op. cit., pp. 155-156. 